\section{Identitas Gender dalam Penggunaan Kata-Kata Tabu Bahasa Jawa di Jawa Timur}

Agustin Anggraeni

Mahasiswa Pascasarjana Prodi Linguistik UGM

Surel: agustin.anggraeni16@gmail.com

INTISARI

Dalam penelitian ini, penulis mengangkat penggunaan kata-kata umpatan, makian, atau hinaan Bahasa Jawa yang digunakan oleh masyarakat Jawa Timur. Tujuan dari penelitian ini adalah untuk mengidentifikasi perbedaan antara masyarakat Jawa Timur laki-laki dan perempuan dalam menggunakan kata-kata tabu Bahasa Jawa dan faktor yang mempengaruhi perbedaan dalam penggunaan kata-kata tersebut. Penulis menggunakan pendekatan kualitatif dalam melakukan penelitian ini, lalu penyajian hasil analisis dipaparkan secara deskriptif. Metode pengumpulan data yang digunakan dalam penelitian ini adalah metode survei. Dalam melakukan survei, peneliti menggunakan kuisioner online yang disebar berdasarkan teknik random sampling kepada 95 responden, terdiri dari 27 laki-laki dan 68 perempuan. Berdasarkan hasil analisis, ditemukan bahwa masyarakat Jawa Timur menganggap bahwa kata jancuk dan asu adalah kata-kata umpatan yang paling kasar, kata ndasmu dan congormu adalah kata makian yang paling kasar, dan kata goblok dan nggatheli adalah kata-kata hinaan yang paling kasar. Laki-laki cenderung memilih leksikal dengan nilai yang paling kasar, seperti jancuk, asu, ndasmu, congormu, nggatheli, goblok ketika berbicara, sedangkan perempuan lebih memperhalus dengan memakai kata kampret, asem, nggaplek'i, pekok, bathukmu, udelmu. Perbedaan-perbedaan tersebut dapat dipengaruhi oleh beberapa faktor, antara lain usia, tingkat pendidikan, pekerjaan, tujuan, mitra tutur, dan pandangan sosial mereka tentang penggunaan kata-kata tabu.

Kata kunci: kata tabu; bahasa dan gender; Bahasa Jawa dialek Jawa Timur

\title{
PENDAHULUAN
}

Terkait dengan penggunaan bahasa di kehidupan bermasyarakat, masyarakat bahasa adalah subjek utama sebagai pemroduksi dan pengguna bahasa karena masyarakat bahasa merupakan aspek utama dalam peristiwa tutur. Rokhman (2013:7) menjelaskan bahwa masyarakat bahasa merupakan suatu kelompok yang memiliki kesamaan, terutama kesamaan bahasa atau variasi bahasa (disebut juga masyarakat bahasa plural). Meskipun masyarakat bahasa didasarkan pada bahasa, sejarah, budaya, politik yang sama, sebagai kelompok sosial, mereka tetap memiliki fitur yang berbeda-beda dari segi gender, kelas sosial, usia, pendidikan, pekerjaan, latar belakang etnik, dan agama. Perbedaan-perbedaan atau heterogenitas masyarakat inilah yang mempengaruhi adanya variasi bahasa.

Variabel-variabel yang bervariasi di dalam variasi bahasa tidak digunakan sembarangan oleh penutur karena tentunya ada faktor-faktor yang berpengaruh ketika peristiwa tutur terjadi, misalnya jenis kegiatan, situasi percakapan, atau mitra tutur. Berdasarkan situasi tutur, manusia menggunakan bahasa yang lebih bervariasi ketika berada di situasi informal karena memang tidak adanya batasan dan aturan yang harus dipatuhi. Dalam realita interaksi secara informal, manusia tidak hanya secara berkelanjutan menggunakan kata-kata standar dan biasa, tetapi juga tidak lepas dari penggunaan yang dianggap tidak biasa atau dikenal dengan istilah taboo words (kata-kata tabu). Berdasarkan penjelasan Jay (2009:I53), taboo words merupakan penjelasan dari leksikon-leksikon emosional yang bersifat menyakitkan hati, menghina, vulgar, menjijikkan, dan tidak sopan. Maka, kata-kata kasar, seperti kampret, jancuk, anjir, dapat dikategorikan sebagai kata tabu.

Penggunaan kata-kata tabu dalam interaksi tidak lepas dari perbedaan gender dalam masyarakat yang mempengaruhi pilihan-pilihan kata dalam berinteraksi. Seperti yang dikatakan oleh Milroy\&Gordon (2003:108), gender mempengaruhi perbedaan bahasa karena masing-masing gender mempunyai bermacam-macam pengalaman hidup. Sehingga, penelitian ini mengangkat 
penggunaan taboo words (kata tabu) yang berfokus pada kata-kata umpatan, makian, atau hinaan yang digunakan oleh laki-laki dan perempuan. Dalam penelitian ini, penulis mengangkat penggunaan kata-kata umpatan, makian, atau hinaan Bahasa Jawa yang digunakan oleh masyarakat Jawa Timur karena masyarakat Jawa Timur merupakan masyarakat bahasa yang lekat dengan Bahasa Jawa dialek Surabaya (dialek Suroboyoan). Bahasa Jawa dialek Surabaya juga dikenal sebagai sumber dari katakata tabu, salah satunya adalah jancuk, yang memang sudah menjadi ciri khas Bahasa Suroboyoan. Sehingga, tujuan dari penelitian ini adalah untuk mengidentifikasi perbedaan antara masyarakat Jawa Timur laki-laki dan perempuan dalam menggunakan kata-kata umpatan, makian, atau hinaan Bahasa Jawa dan faktor yang mempengaruhi perbedaan dalam penggunaan kata-kata tersebut.

Karena keunikan pembahasan tentang kata tabu, beberapa penelitian tentang topik tersebut sudah dilakukan. Salah satunya adalah penelitian Nadia Ghounane yang berjudul A Sociolinguistics View of Linguistics Taboos and Euphemistic Strategies in the Algerian Society : Attitudes and Beliefs in Tlemcem Speech Community. Ghounan melihat nilai sosial kata tabu dalam masyarakat Tlemcen Algeria dan mengidentifikasi hubungan antara penggunaan kata tabu dan cara-cara untuk memperhalus dalam mengujarkan kata-kata tabu. Dalam penelitiannya, Ghounane menemukan bahwa masyarakat Algeria masih menjunjung tinggi nilai kesopanan, sehingga hasil antara penggunaan kata-kata tabu dan euphimisme nya adalah seimbang. Penggunaan kata tabu juga didasarkan pada gender, usia, dan topik yang dibicarakan.

Penelitian ini didasarkan pada teori sosiolinguistik, yaitu salah satu marker sosial yang membedakan penggunaan bahasa adalah gender. Dalam sosiolinguistik, yaitu ilmu yang mengkaji bahasa yang digunakan masyarakat sosial, gender dan sex adalah dua entitas yang berbeda. Penelitian bahasa dan gender diprakarsai oleh Lakoff (1973), di mana ia mengatakan bahwa ada perbedaan pada bahasa wanita dari tataran tata bahasa, pilihan leksikal, frekuensi penggunaan, intonasi, dan unsur supersegmental lain (1973:49). Selanjutnya, Wardhaugh (2015:323) menyebutkan bahwa hubungan bahasa dengan struktur sosial disebut gender preferential language, yang berarti bahwa cara-cara tertentu dalam berujar dan menyampaikan gagasan mencirikan setiap gender, baik feminin maupun maskulin. Dengan demikian, gender feminin dan maskulin membedakan dirinya ketika menyampaikan gagasan.

Spesifiknya, seperti yang sudah disinggung sebelumnya, penggunaan kata-kata tabu dipengaruhi oleh perbedaan aspek sosial yang akhirnya mempengaruhi penggunaan bahasa di lingkungan masyarakat. Tak dapat dihindari, manusia juga mengucapkan kata-kata yang dinilai seharusnya tidak perlu diucapkan, yaitu taboo words. Jay (2009:53) mengatakan bahwa taboo words adalah kata-kata yang mempunyai esensi emosional untuk menyakiti, menghina, memaki, dan dinilai tidak sopan ketika diucapkan. Jay juga menjelaskan tentang motivasi orang menggunakan kata tabu, yaitu tergantung dengan tujuan yang ingin dicapai penutur ketika berbicara. Kata-kata sumpah serapah biasanya diucapkan seseorang untuk menunjukkan sikap marah, frustasi, kaget, atau juga bahagia.

Dalam melakukan penelitian, penulis menggunakan pendekatan kualitatif dan kuantitatif. Dalam melakukan penelitian ini karena dalam penelitian ini, peneliti menggunakan variabel angka dalam bentuk presentase untuk memaparkan perbedaan perbandingan antara gender laki-laki dan perempuan, lalu penyajian analisis akan dipaparkan secara deskriptif. Metode penyediaan data dalam penelitian ini adalah penyebaran kuisioner dengan teknik pengambilan sampel secara random kepada 95 responden, terdiri dari 27 laki-laki dan 68 perempuan. Kriteria responden adalah orang Jawa Timur asli atau orang yang pernah merantau di Jawa Timur dan mereka bisa berbahasa Jawa, serta berusia $>15-<50$ tahun. Selanjutnya, untuk analisis data, penulis memfokuskan pada perbedaan penggunaan kata tabu antara laki-laki dan perempuan dari sisi leksikal dan frekuensi, lalu mengidentifikasi faktor-faktor yang mempengaruhi perbedaan penggunaan kata-kata tabu oleh masyarakat Jawa Timur.

\section{PEMBAHASAN}

\section{Kata-kata Tabu Bahasa Jawa}

Pada umumnya, masyarakat Jawa Timur menggunakan kata-kata tabu Bahasa Jawa untuk mengumpat, memaki, atau menghina. Masing-masing kata umpatan, makian, dan hinaan memiliki variasi leksikal yang berbeda-beda. Kata-kata umpatan yang biasa digunakan masyarakat Jawa Timur berasal dari nama hewan, makanan, dan istilah khas Jawa Timur. Dari yang terkasar (menurut responden) ke yang terhalus adalah asu, jancuk, jangkrik, kampret, asem, dan jambu. Masyarakat 
Jawa Timur juga mempunyai variasi kata-kata makian dari bagian tubuh, seperti congormu (mulutmu dalam Bahasa Jawa kasar sekali), ndasmu (kepalamu), raimu (wajahmu), cangkemmu (mulutmu), udelmu (pusarmu), dan bathukmu (dahimu). Kata-kata terebut mempunyai urutan dari yang terkasar ke terhalus. Selain itu, masyarakat Jawa Timur mempunyai variasi kata-kata hinaan dan sering dipakai dalam percakapan sehari-hari dari yang terkasar ke yang terhalus, seperti goblok, nggatheli, pekok, edan, nggaplek'i, dan katrok. Semua kata tersebut merujuk pada makna tolol, bodoh, kampungan, gila, dan sikap seseorang yang suka memancing emosi orang lain.

\section{Perbedaan Penggunaan Kata-kata Tabu}

\section{a. Leksikal}

Hasil penelitian menunjukkan bahwa laki-laki lebih banyak menggunakan kata-kata umpatan kasar dari pada perempuan. Laki-laki lebih sering menggunakan kata jancuk dan asu, presentasenya paling tinggi yaitu $29 \%$ dan $21 \%$, dimana kata jancuk dan asu merupakan kata yang tingkatannya paling kasar di Jawa Timur. Sementara itu, perempuan lebih sering menggunakan kata kampret (sebanyak 38\%) dan asem (sebanyak 34\%). Ketika laki-laki lebih banyak memilih kata asu, perempuan tidak ada sama sekali yang menggunakan kata asu. Sehingga, pilihan leksikal laki-laki ketika mengumpat memang lebih kasar dari pada perempuan.

Kemudian, laki-laki dan perempuan memiliki pilihan leksikal makian masing-masing. Kata makian yang paling banyak digunakan laki-laki adalah ndasmu dan raimu, yatitu $28 \%$, sedangkan kata yang paling sering dipakai perempuan adalah bathukmu, sebanyak 31\%. Antara kata-kata tersebut, yang tingkat kekasarannya lebih tinggi adalah ndasmu dan raimu. Selanjutnya, penggunaan kata-kata hinaan oleh laki-laki lebih kasar dari pada perempuan. Laki-laki lebih sering menggunakan kata goblok (28\%) dan nggatheli (24\%), yaitu kata-kata yang konotasinya sangat kasar di Jawa Timur. Namun, perempuan lebih banyak menggunakan kata yang lebih halus, seperti nggaplek'i (4I\%) dan edan (I8\%). Dengan demikian, pilihan leksikal hinaan perempuan lebih halus dari pada laki-laki.

\section{b. Frekuensi}

Bukan hanya berbeda secara pemilihan leksikal, laki-laki dan perempuan juga mempunyai perbedaan penggunaan kata-kata umpatan, makian, dan hinaan dalam hal frekuensi. Grafik I berikut akan menunjukkan perbedaan frekuensi penggunaan kata-kata tersebut oleh laki-laki dan perempuan.

\section{Grafik 1. Perbedaan frekuensi penggunaan kata-kata tabu}

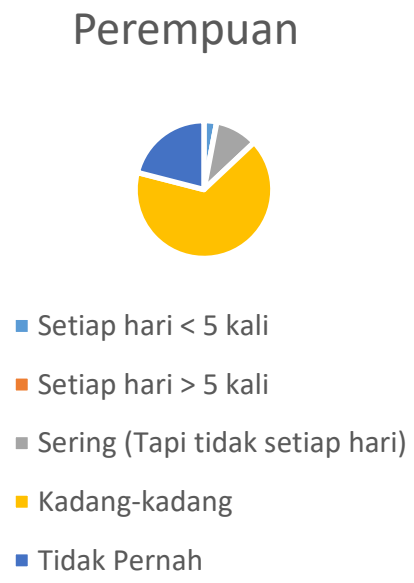

Presentase frekuensi penggunaan masing-masing gender dapat diidentifikasi pada grafik I bahwa meskipun laki-laki dan perempuan mempunyai frekuensi kadang-kadang yang paling besar, tapi terlihat perbedaan pada poin $0 \%$ di masing-masing diagram. Laki-laki menunjukkan angka $0 \%$ untuk poin frekuensi "tidak pernah", sedangkan perempuan menunjukkan angka $0 \%$ untuk poin frekuensi “setiap hari > 5 kali”. Artinya, laki-laki selalu pernah menggunakan kata-kata umpatan, 
hinaan, atau makian, tetapi perempuan tidak pernah menggunakan kata-kata tersebut lebih dari lima kali sehari. Selanjutnya, perempuan juga menunjukkan poin "tidak pernah" mengucapkan kata-kata tersebut, yaitu sebanyak $21 \%$. Oleh karena itu, laki-laki memang lebih sering mengucapkan kata-kata tersebut dari pada perempuan, bahkan beberapa perempuan sama sekali tidak pernah mengucapkannya.

\section{Faktor Yang Mempengaruhi Perbedaan Penggunaan Kata-kata Tabu}

\section{a. Usia}

Salah satu perangkat sosial yang mempengaruhi adanya variasi bahasa adalah usia. Perbedaan usia menimbulkan perbedaan gaya berbicara, ragam bahasa, dan pemilihan leksikal-leksikal ketika berbicara. Berdasarkan hasil penelitian, penulis memaparkan perbedaan penggunaan leksikal untuk mengumpat, memaki, atau menghina dalam Bahasa Jawa antara laki-laki dan perempuan berdasarkan usia. Dalam hal ini, penulis membagi kelompok usia menjadi empat, yaitu usia I5-20, $21-25,2630$, dan usia di atas 30 tahun. Usia maksimal responden penelitian ini adalah 43 tahun.

Berdasarkan data pada tabel di atas, laki-laki sering mengucapkan kata-kata umpatan, makian, atau hinaan yang paling kasar (jancuk, asu, ndasmu, nggatheli) adalah ketika mereka berada pada usia 2I-25 tahun, dengan frekuensi kadang-kadang, sering (tapi tidak setiap hari), bahkan banyak dari mereka mengucapkan kata-kata itu setiap hari dan lebih dari lima kali per hari. Namun, penggunaan kata-kata kasar tersebut semakin berkurang dan menurun tingkat kekasarannya ketika laki-laki menginjak usia 26-30 tahun, yaitu pada usia tersebut lelaki cenderung menggunakan kata asem, cangkemmu, goblok, yang tingkat kekasarannya masih di bawah kata asu, ndasmu, jancuk. Hingga pada usia 30 tahun, responden laki-laki menunjukkan bahwa mereka sudah tidak pernah mengucapkan kata-kata tersebut.

Sementara itu, perempuan lebih banyak persamaan dalam menggunakan kata-kata umpatan, makian, atau hinaan antara rentang usia yang satu dengan rentang usia yang lain. Misalnya pada usia 15-20, 2I-25, dan 26-30, mereka sama-sama sering mengucapkan kata kampret, namun mereka tetap berbeda dalam pengucapan kata makian atau hinaan. Perempuan usia 15-20 lebih menyukai kata udelmu, edan dan perempuan usia 20-25 lebih banyak memakai bathukmu, nggaplek'i. lalu, pada usia 26-30, perempuan sudah tidak lagi mengucapkan kata makian dan hinaan, hanya secara kadang-kadang mengucapkan umpatan kampret. Kemudian, setelah mereka berusia di atas 30 tahun, perempuan sudah tidak lagi menggunakan kata-kata tersebut. Secara garis besar, laki-laki dan perempuan sama-sama mempunyai presentase menurun dalam menggunakan kata-kata tersebut seiring bertambahnya usia, meskipun dalam kelompok usia tertentu mereka memiliki perbedaan.

\section{b. Tingkat Pendidikan}

Selain usia, pendidikan adalah marker sosial yang juga mempengaruhi penggunaan bahasa masyarakat dalam interaksi sosial. Seperti hal nya kelompok usia, penulis mengelompokkan tingkat pendidikan responden, mulai dari tataran SMA, SI, S2, dan S3 untuk melihat bagaimana laki-laki menggunakan kata-kata umpatan, makian, hinaan dalam percakapan sehari-hari. Hasil penelitian menunjukkan bahwa kaum laki-laki, baik yang pendidikannya setingkat SMA atau hingga S3, mereka tidak lepas dari penggunaan kata jancuk ketika mengumpat. Namun, pada tingkat pendidikan terentu, laki-laki mempunyai perbedaan dalam menggunakan kata makian dan hinaan, seperti pada tingkat pendidikan SMA, lelaki lebih kental dengan makian cangkemmu, lalu pada tingkat pendidikan SI dan S2, penggunaan kata makian malah lebih kasar, yaitu ndasmu dan raimu. Kemudian, pada tingkat S3, lelaki cenderung menggunakan kata makian yang lebih halus, yaitu cangkemmu. Hanya saja, pemakaian kata hinaan paling kasar, seperti goblok dan nggatheli masih terdapat dalam semua tataran pendidikan, mulai dari SMA sampai S3.

Sementara itu, perempuan yang mempunyai latar belakang pendidikan SMA sampai dengan S2 mempunyai persamaan penggunaan kata-kata kampret. Hal ini menunjukkan bahwa perempuan lebih menjaga kesopanan dengan mengucapkan kata kampret yang memang nilainya tidak sekasar kata jancuk. Dalam penggunaan kata makian dan hinaan, perempuan berpendidikan SMA cenderung menggunakan kata udelmu, nggaplek'i, lalu perempuan yang berpendidikan SI dan S2 lebih sering memakai kata bathukmu, cangkemmu, dan mereka sama-sama sering memakai kata nggaplek'i. namun, dalam frekuensi pemakaian, meskipun perempuan yang tingkat 
pendidikannya SMA, SI, dan S2 sama-sama menunjukkan frekuensi kadang-kadang, pada tingkat SI dan S2, perempuan banyak juga yang sama sekali tidak pernah mengucapkan kata-kata tersebut. Maka, dalam hal frekuensi, tidak peduli seberapa tinggi tingkat pendidikannya, laki-laki selalu pernah mengucapkan kata-kata tabu, sedangkan perempuan dengan pendidikan SI dan S2 menunjukkan bahwa beberapa mereka sama sekali tidak pernah mengucapkan kata-kata tersebut.

\section{c. Pekerjaan}

Perangkat sosial selanjutnya yang mempengaruhi penggunaan kata tabu oleh masyarakat Jawa Timur adalah pekerjaan. Jenis pekerjaan beserta lingkungannya tentu saja berpengaruh terhadap jenis leksikal dan intensitas pengucapan kata-kata tertentu. Dalam hal ini, penulis menyajikan tabel untuk mengidentifikasi penggunaan kata tabu antara laki-laki dan perempuan berdasarkan pekerjaan yang mereka punya. Karena responden menuliskan berbagai macam pekerjaan mereka, penulis mengelompokkan pekerjaan-pekerjaan tersebut menjadi lima kelompok, yaitu kelompok akademisi (berisi mahasiswa, siswa, tutor, pengajar/pendidik, dan guru), karyawan swasta (tentunya tempat mereka bekerja juga bervariasi), pegawai negeri/BUMN, pengusaha/entrepreneur, dan kelompok yang belum bekerja/ibu rumah tangga.

Hasil penelitian menunjukkan bahwa laki-laki yang berada dalam kelompok pekerjaan sebagai akademisi, karyawan swasta, atau yang belum bekerja, mereka sering menggunakan kata-kata jancuk, cangkemmu, ndasmu, raimu, bathukmu, goblok, dan nggatheli. Sedangkan mereka yang bekerja sebagai pegawai negeri/BUMN, menggunakan kata yang lebih halus, yaitu kampret, jangkrik, dan katrok. Sehingga, kata-kata paling kasar cenderung digunakan oleh akademisi dan karyawan swasta. Di sisi lain, dari frekuensi penggunaannya, kaum laki-laki dengan profesi akademisi lebih sering menggunakan kata-kata tabu, meskipun tidak setiap hari mengucapkan. $\mathrm{Hal}$ ini dipengaruhi oleh pergaulan laki-laki ketika mereka berada dalam dunia sekolah atau kampus, memang banyak dari kalangan mahasiswa biasa sekali mengucapkan kata-kata tabu ketika berbicara antar teman.

Lain hal nya dengan laki-laki, perempuan memiliki ciri khas sendiri dalam menggunakan katakata tabu. Penggunaan variasi kata-kata tabu yang paling banyak adalah kalangan akademisi, karyawan swasta, dan pengusaha. Kata yang paling sering mereka gunakan lagi-lagi adalah kampret, asem, bathukmu, nggaplek'i, yang memang kata-kata ini mempunyai nilai kasar yang lebih rendah. Bahkan, perempuan yang bekerja sebagai pegawai negeri/BUMN dan ibu rumah tangga, mereka mempunyai variasi kata yang lebih sedikit dan bentuknya paling halus dibandingkan kata-kata yang lain.

Lalu, berdasarkan frekuensi penggunaan, semua profesi menunjukkan bahwa mereka hanya mengucapkan kata-kata tabu secara kadang-kadang. Terlebih, beberapa perempuan dengan profesi akademisi dan ibu rumah tangga mengatakan bahwa mereka tidak pernah menggunakan kata-kata tersebut. Dengan demikian, penggunaan kata-kata tabu di kalangan perempuan memang lebih rendah, dimana laki-laki yang berprofesi sebagai akademisi, karyawan swasta, pegawai negei/BUMN, pengusaha, atau yang belum bekerja, mereka semua pernah mengucapkan kata-kata tabu dalam percakapan, sedangkan perempuan yang berprofesi sebagai akademisi dan ibu rumah tangga, ada yang tidak pernah menggunakan kata-kata tersebut.

\section{d. Tujuan}

Penulis memfokuskan tujuan secara umum digunakannya kata-kata tabu tersebut oleh masyarakat Jawa Timur, yaitu untuk melampiaskan kemarahan, meledek atau bercanda, dan menghina. Data penelitian menunjukkan bahwa presentase tertinggi tujuan penggunaan katakata tabu untuk meledek/bercanda, diikuti oleh melampiaskan kemarahan. Laki-laki ternyata tidak memiliki intensi menghina mitra tutur ketika mengucapkan kata umpatan. Sedikit berbeda dengan laki-laki, perempuan mempunyai tujuan menghina ketika mengucapkan kata umpatan, namun perempuan memiliki presentase tertinggi dalam tujuan meledek/bercanda. Artinya, lakilaki menunjukkan tingkat emosi yang lebih tinggi dari pada wanita ketika mengucapkan katakata umpatan, sedangkan perempuan lebih kental dalam tujuan bercanda. 


\section{e. Mitra Tutur}

Perbedaan penggunaan variasi kata-kata tabu antara laki-laki dan perempuan juga dapat diidentifikasi dari mitra tutur mereka. Antara laki-laki dan perempuan tentunya mereka mempunyai kecenderungan kepada siapa mereka biasanya menggunakan kata-kata tersebut. Dalam diagram 2 berikut penulis mencoba memaparkan perbedaan lawan bicara yang menjadi objek ketika laki-laki dan perempuan mengucapkan kata-kata tabu umpatan, makian, dan hinaan Bahasa Jawa.

Grafik 2. Presentase perbedaan mitra tutur kedua gender

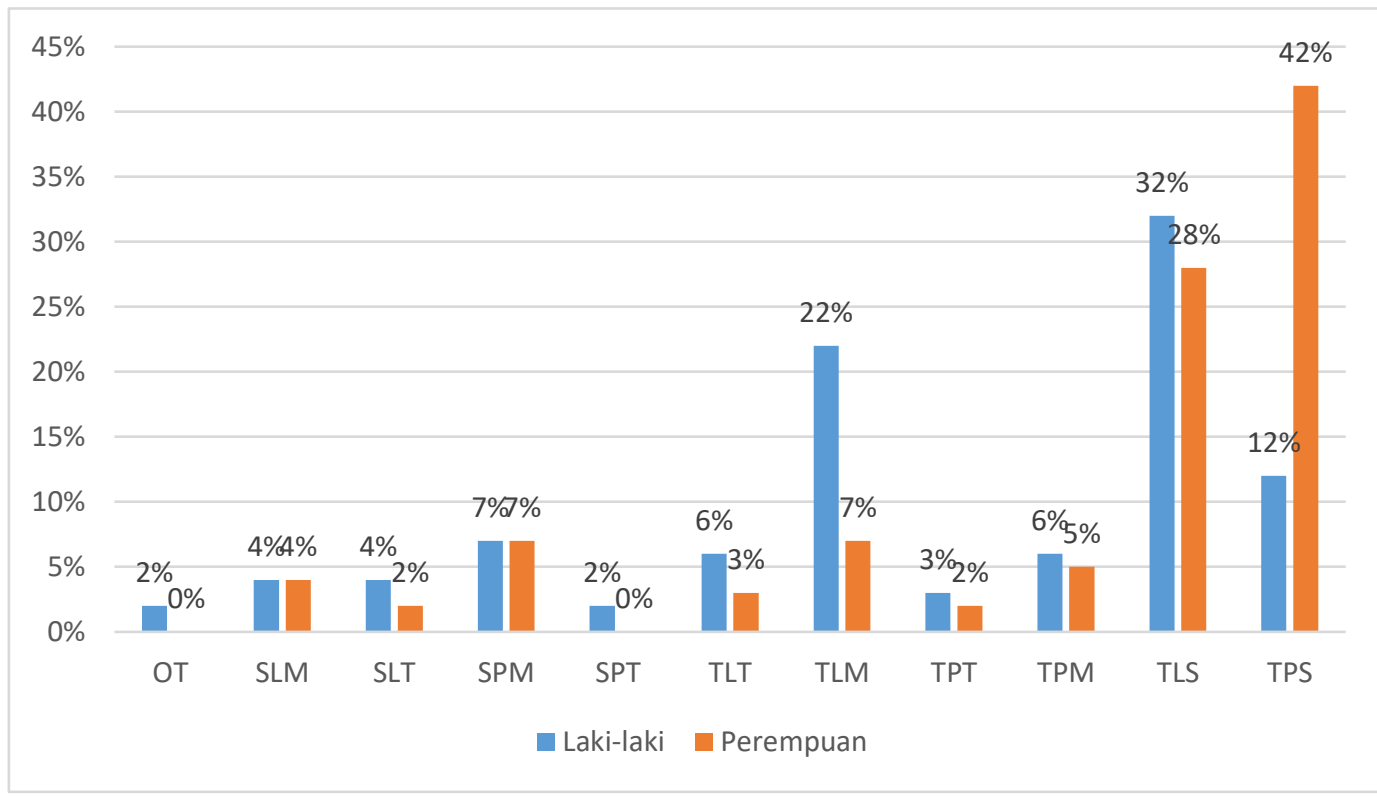

\section{KETERANGAN:}

OT : Orang tua : TLM : Teman laki-laki yang lebih muda

SLM : : Saudara laki-laki yang lebih muda TPT : Teman perempuan yang lebih tua

SLT : Saudara laki-laki yang lebih tua : TPM : Teman perempuan yang lebih muda

SPM : : Saudara perempuan yang lebih muda TLS : Teman laki-laki seumuran

SPT : Saudara perempuan yang lebih tua TPS :Teman Perempuan seumuran

TLT : : Teman laki-laki yang lebih tua

Dari data presentase pada diagram batang dapat terlihat adanya perbedaan lawan tutur antara laki-laki dan perempuan yang dapat mempengaruhi penggunaan kata-kata tabu. Kaum laki-laki cenderung menggunakan kata-kata tabu kepada teman laki-laki seumuran (TLS), dimana presentasinya adalah yang paling tinggi, sebanyak 32\%. Selain kepada teman laki-laki seumuran, kaum lelaki juga sering mengucapkan kata-kata tabu kepada teman laki-laki yang lebih muda (TLM), yaitu presentasinya sebanyak $22 \%$. Kepada teman perempuan seumuran (TPS), laki-laki tidak terlalu sering mengucapkan kata-kata tabu, presentasinya hanya $12 \%$.

Selebihnya, kepada teman perempuan yang lebih muda (TPM), teman perempuan yang lebih tua (TPT), teman laki-laki yang kebih tua (TLT), saudara perempuan yang lebih tua (SPT), saudara perempuan yang lebih muda (SPM), saudara laki-laki yang lebih tua (SLT), dan saudara laki-laki yang lebih muda (SLM), kaum laki-laki jarang menggunakan kata-kata tabu, terlihat dalam presentasi yang hanya sekitar $2 \%$ hingga $7 \%$. Uniknya, kepada orang tua (OT) mereka, laki-laki bisa saja menggunakan kata-kata tabu itu, terbukti dengan presentase $2 \%$. Tentunya, tujuan penggunaannya adalah lebih ke bercanda, bukan melampiaskan kemarahan, apalagi menghina.

Berbeda dengan laki-laki yang menggunakan kata-kata tabu kepada semua daftar mitra tutur, termasuk orang tua (OT) dan saudara perempuan yang lebih tua (SPT), data perempuan sama sekali tidak menunjukkan adanya kedua mitra tutur tersebut ketika mereka mengucapkan katakata tabu. Hal ini terbukti dari presentase poin OT dan SPT yang hanya ada dalam angka $0 \%$. Selain itu, perempuan juga lebih sering menggunakan kata-kata tabu ketika berbicara kepada 
teman perempuan seumuran (TPS), yaitu angka tertinggi sebanyak 42\%, kemudian diikuti teman laki-laki seumuran (TLS) sebanyak $32 \%$.

Kepada mitra tutur yang lain, seperti teman perempuan yang lebih muda (TPM), teman perempuan yang kebih tua (TPT), teman laki-laki yang lebih muda (TLM), teman laki-laki yang lebih tua (TLT), saudara perempuan yang lebih muda (SPM), saudara laki-laki yang lebih tua (SLT), dan saudara laki-laki yang lebih muda (SLM), perempuan jarang mengucapkan kata-kata tabu karena presentasenya juga di bawah 10\%. Jadi, perempuan lebih sering menggunakan katakata tabu kepada teman perempuan seumuran (TPS), sedangkan laki-laki lebih sering menggunakannya kepada teman laki-laki seumuran (TLS). Artinya, antara laki-laki dan perempuan mempunyai teman sepermainan masing-masing dimana mereka nyaman-nyaman saja ketika mengucapkan kata-kata tersebut.

\section{f. Pandangan Sosial}

Yang terakhir, penulis mencoba mengidentifikasi perbedaan pandangan sosial tentang kata-kata umpatan, makian, dan hinaan Bahasa Jawa di lingkungan masyarakat Jawa Timur karena pandangan masing-masing gender dapat mempengaruhi intensitas penggunaan kata-kata tersebut. Hasil penelitian menunjukkan bahwa penilaian laki-laki tentang penggunaan kata-kata tabu adalah sebagian besar mereka meyakini kata-kata tersebut merupakan sesuatu yang tidak sopan, tapi biasa diucapkan dalam obrolan santai (informal), presentasenya sebanyak $60 \%$. Mereka juga memandang kata-kata tabu sebagai sesuatu yang dapat mengakrabkan hubungan satu sama lain, presentasenya sebanyak $40 \%$. Tidak ada anggapan bagi mereka bahwa kata tabu adalah sesuatu yang sama sekali tidak patut diucapkan oleh siapapun di publik, baik situasi formal maupun informal. Artinya, laki-laki menganggap kata-kata tabu sebagai tanda solidaritas meskipun kadang sesuatu tersebut dianggap tidak sopan.

Berbeda sekali dengan laki-laki, beberapa perempuan menilai bahwa kata-kata tabu merupakan sesuatu yang sama sekali tidak patut diucapkan oleh siapapun, terbukti dengan presentasi penilaian sebanyak $16 \%$. Di samping itu, penilaian tentang sesuatu yang dapat mengakrabkan menunjukkan angka $28 \%$ dan sesuatu yang tidak sopan, tapi biasa diucapkan menunjukkan angka $56 \%$. Presentase penilaian keakraban dan sesuatu yang tidak sopan tapi boleh diucapkan pada perempuan lebih rendah presentasenya dibandingkan dengan laki-laki. Artinya, dari sisi solidaritas, laki-laki memang lebih tinggi sekalipun cara membangun solidaritas tersebut adalah dengan mengucapkan kata umpatan, makian, atau hinaan.

\section{KESIMPULAN}

Antara laki-laki dan perempuan memiliki perbedaan leksikal dan frekuensi dalam menggunakan kata-kata tersebut. Laki-laki cenderung memilih leksikal dengan nilai yang paling kasar, seperti jancuk, asu, ndasmu, congormu, nggatheli, goblok ketika berbicara, sedangkan perempuan lebih memperhalus dengan memakai kata kampret, asem, nggaplek'i, pekok, bathukmu, udelmu. Secara intensitas, laki-laki lebih sering mengucapkan kata-kata tersebut dari pada perempuan karena beberapa laki-laki mengucapkan kata tersebut sebanyak lebih dari lima kali dalam sehari dan banyak juga dari mereka mengucapkannya secara kadang-kadang, sedangkan perempuan menunjukkan frekuensi kurang dari lima kali dalam sehari, kadang-kadang, bahkan tidak pernah. Perbedaanperbedaan tersebut dapat dipengaruhi oleh beberapa faktor, antara lain usia, tingkat pendidikan, pekerjaan, tujuan, mitra tutur. Selanjutnya, ketika perempuan tidak memiliki tujuan menghina ketika mengucapkan kata-kata hinaan, beberapa laki-laki ternyata memiliki intensi penghinaan sungguhan. Begitu juga dengan mitra tutur mereka menggunakan kata-kata tersebut, bahwa lakilaki sering mengucapkan kata tabu kepada teman laki-laki seumuran, sedangkan perempuan lebih sering kepada teman perempuan seumuran.

\section{DAFTAR PUSTAKA}

Coates, Jennifer. 2013. Women, Men, and Language. New York : Routledge 
Ghounane, Nadia. 20 I4. A Sociolinguistic View of Linguistic Taboos and Euphemistic Strategies in the Algerian Society: Attitudes and Beliefs in Tlemcen Speech Community. International Journal of Research in Applied Natural and Social Science, Volume 2, 73-88

Holmes, Janet. 2013. An Introduction to Sociolinguistics. New York : Routledge

Jay, Timothy. 2009. The Utility and Ubiquity of Taboo Words. Perspectives on Psychological Science, Volume 4, |53-16|

Lakoff, Robin. 1973. Language and Woman's Place. Language in Society, Vol. 2, 45-80

Meyerhoff, Miriam. 2006. Introducing Sociolinguistics. New York : Routledge

Milroy, Lesley\&Gordon, Matthew. 2003. Sociolinguistics. Oxford : Blackwell Publishing

Rokhman, Fathur. 2013. Sosiolinguistik. Yogyakarta : Graha IImu

Wardhaugh, Ronald\&Fuller, Janet M. 2015. An Introduction to Sociolinguistics. Sussex : Wiley Blackwell

Wardhaugh, Ronald. 2006. An Introduction to Sociolinguistics. Oxford : Blackwell Publishing 